\title{
Do non-steroidal anti-inflammatory drugs adversely affect stress fracture healing? A short review
}

\author{
P Wheeler, M E Batt
}

Br J Sports Med 2005;39:65-69. doi: 10.1136/bjsm.2004.012492

A literature search was performed to determine whether non-steroidal anti-inflammatory drugs (NSAIDs) adversely affect the healing of stress fractures. Evidence exists from laboratory studies and animal subjects that NSAIDs can affect fracture healing. This link has not been proved or disproved in human subjects, particularly for stress fractures. In view of the high usage of NSAIDs in treating musculoskeletal disorders, research is required to investigate whether the healing of stress fractures is affected by these drugs.

See end of article for authors' affiliations ....................

Correspondence to: Dr Wheeler, Leicester General Hospital, University Hospital of Leicester NHS Trust, Department of Sports Medicine, Gwendolen Road, Leicester LE5 4PW UK; patrickwheeler@ doctors.org.uk

Accepted 22 August 2004
$\mathrm{N}$ on-steroidal anti-inflammatory drugs (NSAIDs) are often recommended for alleviation of pain and inflammation from stress fractures, and their use has been described in case reports of stress fractures. ${ }^{1-3}$ However, NSAIDs affect prostaglandin synthesis, and, as prostaglandins have been shown to be essential for normal bone turnover and fracture healing, the use of NSAIDS may ultimately affect bone healing by inhibiting maturation of the callus. Animal studies involving NSAIDs have shown a delay in healing time and non-union of fractures. However, human studies have produced inconclusive results, but sources such as Bennell and Bruckner ${ }^{4}$ are advising against the use of NSAIDs in the treatment of stress fractures.

NSAIDs are a chemically diverse group of medicines available for many different routes of administration. In the United Kingdom, a few NSAIDs are on restricted sale to the public, but most have a prescription only medicine licence. NSAIDs are responsible for more than 2000 deaths a year in the United Kingdom and for nearly one quarter of all adverse drug reactions reported to the Committee on the Safety of Medicines. ${ }^{5}$

NSAIDs have both central and peripheral analgesic effects. They work peripherally by inhibiting the cyclo-oxygenase pathway, thereby reducing prostaglandin production which would otherwise potentiate the effect of additional mediators of inflammation such as histamine and bradykinin. NSAIDs are therefore most effective in alleviating types of pain that cause amplification of basic pain responses by prostaglandins, such as inflammation. ${ }^{5}$ Their methods of action centrally are less well understood, as certain NSAIDs will affect pain that is unrelated to inflammation. ${ }^{5}$

NSAIDS are currently licensed for use in all musculoskeletal disorders, and the British
National Formulary ${ }^{6}$ list of the recognised side effects includes gastrointestinal discomfort, nausea, diarrhoea, and occasionally bleeding and ulceration. Other side effects include hypersensitivity, angioedema, and bronchospasm, but effects on bone metabolism or impairment of fracture healing are not currently listed.

Stress fractures were first described by Burrows $^{6 a}$ in 1956 in a series of five ballet dancers. Most stress fractures affect the lower legs or metatarsals, but an estimated $1 \%$ occur at the femoral neck. ${ }^{7}$ It is generally accepted that certain stress fractures are at risk of progression to complete fractures. Studies have shown that stress fractures start with periosteal oedema, which can be visualised by magnetic resonance imaging, followed by marrow involvement, then ultimately a cortical stress fracture. ${ }^{1}$ Various treatments have been suggested for non-healing stress fractures, including controlled rest, braces, and surgery. ${ }^{4}$ Importance is now placed on maintaining fitness during the recovery process, through cross training and the modification of any risk factors before a protected return to sport occurs. ${ }^{4}$ Although many stress fractures will heal spontaneously, many factors, including continued mechanical stress at the fracture site, smoking, and possibly NSAIDs, may impair this healing. ${ }^{4}$

For fracture healing to progress, mesenchymal cells must differentiate to form chondrocytes and osteoblast precursors. Previous studies have shown that the cyclo-oxygenase pathway has a vital role during both osteogenesis and chondrogenesis by producing prostaglandin E2. ${ }^{9}{ }^{10}$ Cyclooxygenase is present in many tissues as a constitutive isoform (COX-1). However, at sites of inflammation, cytokines stimulate the induction of COX-2, a second isoform. Work in 2002 by Zhang $e t \mathrm{al}^{11}$ suggests that COX-1 has a role in bone homoeostasis, but that COX-2 is a stress response gene which acts in inflammation by regulating the induction of several genes (cbfa-l and osterix) to mediate normal skeletal repair by facilitating osteogenesis.

Studies initially performed in the 1970s and 1980s showed that NSAIDs may interfere with fracture healing. However, an article by Penman in the New Scientist in 2002, ${ }^{12}$ which was widely reported in the lay and medical press, highlighted this subject and put it once more into the public domain. On the basis of previously published animal and human research, Penman discussed whether NSAIDs could interfere with fracture healing.

This review sets out to investigate the evidence base for NSAIDs affecting stress fracture healing. 
Table 1 Animal studies on the effect of non-steroidal anti-inflammatory drugs on bone healing: five randomised controlled trials using rats

\begin{tabular}{|c|c|c|c|c|}
\hline Reference & Year & Population & Intervention & Result \\
\hline Allen et $a l^{16}$ & 1980 & $\begin{array}{l}210 \text { male rats with fractured } \\
\text { radius and ulna }\end{array}$ & $\begin{array}{l}\text { Indomethacin (1-4 mg/kg/day), aspirin } \\
\text { (100-300 mg/kg/day) and control groups }\end{array}$ & $\begin{array}{l}\text { Retardation of fracture healing with all } \\
\text { doses of indomethacin studied and high } \\
\text { dose aspirin }\end{array}$ \\
\hline Altman et $a l^{17}$ & 1995 & Rats with femoral fractures & $\begin{array}{l}\text { Indomethacin ( } 1 \mathrm{mg} / \mathrm{kg} / \text { day), ibuprofen } \\
\text { ( } 30 \mathrm{mg} / \mathrm{kg} / \text { day) and control groups }\end{array}$ & $\begin{array}{l}\text { Inhibition of fracture repair } \\
\text { characterised by delayed maturation of } \\
\text { the callus; found to be reversible after } \\
\text { cessation of indomethacin, but not } \\
\text { ibuprofen }\end{array}$ \\
\hline Elves et $\left.a\right|^{18}$ & 1982 & $\begin{array}{l}83 \text { rats of various ages with } \\
\text { surgically created vertebral fractures }\end{array}$ & $\begin{array}{l}\text { Indomethacin ( } 4 \mathrm{mg} / \mathrm{kg} / \text { day) and control } \\
\text { group }\end{array}$ & $\begin{array}{l}\text { Delay and impairment of bone repair in } \\
\text { mature rats only; reversed on cessation }\end{array}$ \\
\hline Hogevold et al ${ }^{19}$ & 1992 & $\begin{array}{l}72 \text { male rats with mid-shaft femoral } \\
\text { fractures. Involving a complete- } \\
\text { osteotomy and a partial-osteotomy } \\
\text { group }\end{array}$ & $\begin{array}{l}\mathrm{NaCl} \text { group, indomethacin group } \\
(2 \mathrm{mg} / \mathrm{kg} / \text { day), steroid group } \\
\text { (methylprednisolone } 2 \mathrm{mg} / \mathrm{kg} \text { ) and control } \\
\text { group }\end{array}$ & $\begin{array}{l}\text { Indomethacin inhibited fracture healing; } \\
\text { this effect was less in the partial } \\
\text { osteotomy group than in the complete } \\
\text { osteotomy group }\end{array}$ \\
\hline Sudmann et $a l^{22}$ & 1982 & $\begin{array}{l}48 \text { adolescent male rats with } \\
\text { femoral shaft fractures }\end{array}$ & $\begin{array}{l}\text { Indomethacin ( } 2 \mathrm{mg} / \mathrm{kg} / \text { day) and control } \\
\text { groups. }\end{array}$ & $\begin{array}{l}\text { No effect on the ordered bone growth } \\
\text { and remodelling }\end{array}$ \\
\hline
\end{tabular}

\section{METHODS}

Literature searches for original publications and reviews were conducted using Cochrane, Embase, Medline, SPORTDiscus, and Your Journals@Ovid. Articles were then pooled for appraisal. Dates searched covered the entire history of these databases. Keywords used were: anti-inflammatory; bone; COX; cyclo-oxygenase; fracture \pm stress; ibuprofen; indomethacin; healing; NSAIDs.
Specific journals were also individually searched using the appropriate websites. These included the British Journal of Sports Medicine and the BMJ. Issues of the publications Bandolier, Drugs \& Therapeutics Bulletin, and MeReC Bulletin were all searched from 1993 to November 2003, as was the current edition of the BMJ's publication Clinical Evidence. The British National Formulary and several widely available pharmacology texts were also used for reference.

Table 2 Human studies on the effect of non-steroidal anti-inflammatory drugs (NSAIDS) on bone healing

\begin{tabular}{|c|c|c|c|c|c|}
\hline Reference & Year & Population & Intervention & Result & Quality \\
\hline Adolphson et $a l^{23}$ & 1993 & $\begin{array}{l}\text { Double blind randomised study of } \\
\text { postmenopausal women with displaced } \\
\text { Colles fractures }\end{array}$ & Piroxicam $v$ placebo & $\begin{array}{l}\text { No significant delay in } \\
\text { healing }\end{array}$ & A \\
\hline Butcher and Marsh ${ }^{25}$ & 1996 & $\begin{array}{l}\text { Retrospective analysis of } 94 \text { patients } \\
\text { with tibial fractures }\end{array}$ & Any NSAIDs & $\begin{array}{l}\text { More likely to have delayed } \\
\text { healing with NSAIDs }\end{array}$ & B \\
\hline Glassman et $a l^{30}$ & 1997 & $\begin{array}{l}\text { Retrospective analysis of } 288 \text { spinal } \\
\text { surgery patients }\end{array}$ & $\begin{array}{l}\text { Postoperative intramuscular } \\
\text { ketorolac }\end{array}$ & $\begin{array}{l}\text { Significantly increased risk } \\
\text { of non-union after NSAIDs }\end{array}$ & B \\
\hline $\operatorname{Khan}^{26}$ & 1997 & $\begin{array}{l}\text { Retrospective analysis of patients with } \\
\text { clavicle fractures }\end{array}$ & Any NSAID & $\begin{array}{l}\text { Increased rate of non-union } \\
\text { with NSAIDs }\end{array}$ & B \\
\hline Alho et al. ${ }^{27}$ & 1999 & $\begin{array}{l}\text { Survey of } 165 \text { elderly patients with } \\
\text { femoral neck fractures }\end{array}$ & Standard treatments & No mention of NSAIDs & B \\
\hline Perlman and Thordarson ${ }^{29}$ & 1999 & $\begin{array}{l}\text { Retrospective analysis of } 67 \text { ankle } \\
\text { fusions }\end{array}$ & None & $\begin{array}{l}\text { Non-union associated with } \\
\text { open trauma, smoking, } \\
\text { alcohol, diabetes, and illicit } \\
\text { drug use; no mention of } \\
\text { NSAIDs }\end{array}$ & B \\
\hline Giannoudis et $a l^{2}$ & 2000 & $\begin{array}{l}\text { Retrospective analysis of } 32 \text { patients } \\
\text { with non-union of the femoral } \\
\text { diaphysis ( } 67 \text { controls) }\end{array}$ & $\begin{array}{l}\text { Any, mainly diclofenac and } \\
\text { ibuprofen }\end{array}$ & $\begin{array}{l}\text { Significant association } \\
\text { between NSAIDs and non- } \\
\text { union }\end{array}$ & B \\
\hline Van Staa et al ${ }^{9}$ & 2000 & $\begin{array}{l}\text { Retrospective cohort of } 500000 \\
\text { patients taking NSAIDs in primary } \\
\text { care with matched controls }\end{array}$ & Any NSAID & $\begin{array}{l}\text { Not supportive of } \\
\text { overall effect on bone } \\
\text { metabolism } \\
\text { No differences in fracture } \\
\text { risk between regular and } \\
\text { irregular NSAID users }\end{array}$ & B \\
\hline Karladani et a ${ }^{28}$ & 2001 & 100 consecutive tibial shaft fractures & None & $\begin{array}{l}\text { Increased rates of non-union } \\
\text { with high energy trauma } \\
\text { and with open fractures; no } \\
\text { mention of NSAIDs }\end{array}$ & B \\
\hline Reuben et $a l^{14}$ & 2001 & $\begin{array}{l}\text { Retrospective analysis of } 106 \text { spinal } \\
\text { surgery patients }\end{array}$ & Rofecoxib & $\begin{array}{l}\text { No significantly increased } \\
\text { risk of non-union compared } \\
\text { with studies without NSAIDs }\end{array}$ & B \\
\hline Clough $^{3}$ & 2002 & $\begin{array}{l}\text { Case report of femoral neck stress } \\
\text { fracture }\end{array}$ & Not clear from article & $\begin{array}{l}\text { Given NSAIDs before non- } \\
\text { union }\end{array}$ & B \\
\hline Burd et $\left.a\right|^{24}$ & 2003 & $\begin{array}{l}112 \text { patients at risk of heterotopic } \\
\text { ossification after open reduction and } \\
\text { external fixation of acetabular fracture }\end{array}$ & $\begin{array}{l}\text { Prospectively randomised to } \\
\text { radiation therapy } v \\
\text { indomethacin } v \text { no prophylaxis }\end{array}$ & $\begin{array}{l}\text { Patients who received } \\
\text { indomethacin had a greater } \\
\text { risk of non-union of the long } \\
\text { bones than those who either } \\
\text { received radiotherapy or no } \\
\text { prophylaxis }\end{array}$ & A \\
\hline
\end{tabular}


Articles were filtered to English language and included animal studies. Articles were discarded by the first author (PW) if they were not deemed to assist in answering the underlying question.

Levels of evidence were graded according to standard criteria of quality: level A, meta-analysis or randomised controlled trials; level B, other scientific studies; level C, consensus or expert opinions. ${ }^{13}$

No publications were found that dealt specifically with stress-type fractures and NSAIDs, so the literature search was extended to include all fracture types. Conclusions were drawn from these as appropriate.

\section{RESULTS \\ Studies investigating the effects of NSAIDs on bone healing}

There remains a paucity of research on this topic, despite several authors highlighting the theoretical risks that NSAIDs may have on wound and bone healing. Work has been carried out on animal subjects and different NSAIDs, and research has been performed investigating the risk in human subjects with complete fractures or non-union after surgical procedures. It is mostly from these studies that any information on the healing of stress fractures and NSAIDs must be extrapolated.

NSAIDs are often used after soft tissue and bony injury and in the period after orthopaedic and other surgical procedures. ${ }^{14}$ Some authors believe that COX-2 inhibitors may be safer alternatives to traditional NSAIDs because one study involving rabbit models showed no impairment of healing after spinal surgery. However, we are reminded that NSAIDs have been shown to affect bone osteogenesis during fracture healing, and very limited work has been published comparing NSAIDs and different COX-2 inhibitors. ${ }^{15}$

\section{Animal studies}

Animal studies (table 1) have shown that NSAIDs, including indomethacin ${ }^{16-21}$, aspirin, ${ }^{16}$ and ibuprofen, ${ }^{17}$ can all affect healing of a variety of fractures, including those affecting the rat forelimb, ${ }^{16}$ vertebra, ${ }^{18}$ or femur. ${ }^{19}$ All doses of indomethacin appear to cause delayed bone healing, but aspirin only delays healing at levels approaching toxicity. ${ }^{16}$ The healing of partial osteotomies was impaired to a lesser extent than healing of complete osteotomies. This is thought to be due to increased mechanical stability of the fracture. ${ }^{19}$

Prostaglandin appears to be an essential component for bone healing, with delays in healing resulting from a delay in maturation of the callus rather than direct effects on collagen synthesis. ${ }^{161721}$ This delay is reversible on the cessation of indomethacin but not ibuprofen. ${ }^{17}{ }^{18}$

The processes of growth and development and those of bone repair appear to use different pathways, as indomethacin appears to have no effect on ordered bone growth and remodelling of rat femurs. ${ }^{22}$

\section{Human studies}

Although two of the studies examining the impact of NSAIDs on bone healing after fractures in humans were prospective, ${ }^{23}{ }^{24}$ the majority were retrospective (table 2 ). Studies on patients treated after sustaining a variety of traumatic fractures, including Colles-type, ${ }^{23}$ tibia, ${ }^{25}$ clavicle, ${ }^{26}$ non-union of the femoral diaphysis, ${ }^{2}$ and acetabular, ${ }^{24}$ produced inconsistent results, with one study showing no difference and the remainder showing delayed healing or an increased risk of non-union. Several other large, high quality studies of healing of traumatic fractures did not mention NSAIDs. ${ }^{27-29}$

Of the two prospective studies in humans, the double blinded study by Adolphson et $a^{23}$ on recovery and bone density after Colles fracture showed no effect of NSAIDs, unlike the study by Burd et al, ${ }^{24}$ which looked at patients at risk of heterotopic ossification after surgical fixation for acetabular fractures. These were randomly allocated to prophylaxis, using either radiation treatment or indomethacin, or to a control group. Patients who received indomethacin had a greater risk of non-union of the long bones than those who received either radiotherapy or no prophylaxis. The retrospective studies of healing and recovery after fractures all showed an adverse effect on bone healing, either delayed bone healing or an increased rate of non-union, by the administration of NSAIDs.

Clough $^{3}$ highlights the case of a 55 year old man who had suffered a stress fracture of the femoral neck. Diagnosis was delayed by 10 weeks, during which time he was given several courses of NSAIDs for analgesia. By the time it was diagnosed, the stress fracture had displaced and required closed reduction and stabilisation using a dynamic hip screw. Although the author made no connection between the administration of the NSAIDs and the non-union of the stress fracture, it highlights how often NSAIDs are used.

Several studies looked at the effects of NSAIDs on bone healing after spinal surgery. ${ }^{14}{ }^{30}$ Non-union was found to be up to five times more likely in patients who received intramuscular ketorolac after the operation, ${ }^{30}$ but no difference was found in those receiving rofecoxib compared with controls. ${ }^{14}$ The fivefold increase in the study by Glassman et $\mathrm{al}^{30}$ was greater than that attributed to other risk factors, including smoking, but did involve large doses of intramuscular ketorolac, which has different pharmacokinetics from oral doses. ${ }^{31}$

NSAIDs appear to have no overall effect on the risk of fractures. Van Staa $e^{2} a l^{9}$ examined the fracture risks of more than 200000 regular NSAID users, a similar number of incidental NSAID users, and matched controls, all within the primary care setting. Differing from previously published smaller studies, this study did not support an overall effect of NSAIDs on bone metabolism, and there were no significant differences in fracture risk between regular and incidental NSAID users. It did indicate that regular NSAID users had a higher risk of fracture than non-NSAID controls, which appeared to decrease as duration of treatment increased, but did not fall below baseline levels. This study showed no consistent differences in fracture risk between different NSAIDs, which is different from previously published studies. Although many confounding factors were taken into account, other factors such as previous bone density, diet, and level of exercise could not be taken into account.

\section{Reviews}

In 2001, Bandolier (www.ebandolier.com) published a review $^{32}$ of the study by Van Staa, ${ }^{9}$ which was followed up by an extended review published as Bandolier Extra. ${ }^{31}$ These are non-peer reviewed, independent publications concerned with evidence based health care which look at published literature located by a combination of a search of PubMed using unspecified free text terms and a review of the Cochrane Library. No specific information was readily available detailing inclusion and exclusion criteria for the reviews, and formal weighting was not given to evidence. These two reviews discuss laboratory experiments that show that NSAIDs have an effect on bone metabolism in animal subjects and appraise the research by Van Staa et al, ${ }^{9}$ which contradicts this evidence in humans. The second review examines other studies, including a Cochrane review examining heterotopic bone formation after hip replacement. This review does not mention failure of bone healing after use of NSAIDs, nor do the articles by Glassman $e t a l^{30}$ and Reuben $e t \mathrm{al}^{14}$ on the effects of NSAIDs and COX-2 inhibitors after spinal surgery, or that by Adolphson $e a^{23}$ on the effects 
of NSAIDs after Colles fractures. It also discusses several studies on bone healing that make no mention of NSAIDs, including those of Perlman and Thordarson, ${ }^{29}$ Alho et al, ${ }^{27}$ and Karladani et al. ${ }^{28}$ The review concludes that there is good clinical evidence showing inhibition of fracture healing from animal studies, but that this may not be applicable to clinical situations involving humans. The reviews conclude that there is only reliable evidence for NSAIDs affecting heterotopic bone formation, but not fracture healing, and suggest that any significant effect on fracture healing in humans is unlikely to have been missed.

In a recently published sports medicine textbook, Bennell and Brukner ${ }^{4}$ discuss the management of stress fractures, and conclude, after a personal communication, that there is a theoretical risk that some NSAIDs may slow or prevent repair of stress fractures, but accept that there are no high quality formal trials from which to draw conclusions.

Penman ${ }^{12}$ reintroduced this subject to the public's awareness in the New Scientist in 2002. This examined evidence from several trials with animal and human subjects, but no mention was made of how trials were identified, and no inclusion or exclusion criteria for consideration were specified. The article comments that a trial of rofecoxib in rats inhibited fracture healing, but did not give specific figures detailing risk. The article states that NSAIDs, including ibuprofen and indomethacin, delay fracture healing by one or two weeks in rats, which is the equivalent to slowing healing by $20-25 \%$, but the trials from which these figures were gleaned are not readily identified. The article concludes with the suggestion that people with healing fractures should avoid NSAIDs and that further investigation is required.

\section{DISCUSSION}

NSAIDs can either reversibly or irreversibly block the cyclooxygenase pathway, thereby inhibiting prostaglandin synthesis. From the available evidence it is still unclear whether this inhibition significantly impairs healing of stress fractures in humans.

Animal studies have shown that NSAIDs delay healing in complete fractures. One study showed that NSAIDs impaired healing to a greater extent in a complete osteotomy group than in the partial osteotomy group. This was thought to be due to increased mechanical stability, adding another confounding variable to the issue. Many of the animal studies, however, used drugs, doses, and route of administration (typically indomethacin at $1-4 \mathrm{mg} / \mathrm{kg} /$ day intravenously in rats) that may not represent equivalent pharmacokinetics and pharmacodynamics to those used in human subjects. The equivalent dose in an $80 \mathrm{~kg}$ man would be $80-320 \mathrm{mg} /$ day via a different route of administration. This would exceed the licensed dose of 50-200 mg/day in oral divided doses for analgesia. ${ }^{6}$

In studies on human subjects, there is a lack of high quality evidence. NSAIDs are often used in a wide range of musculoskeletal conditions, so it is to be expected that they are often mentioned in case reports involving stress fractures. There were no trials that looked directly at stress fracture healing with NSAID use, and, as the animal studies show that the healing processes may be impaired by NSAIDs to a different extent for different types of fracture, the interpretation of results from trials involving complete frank fractures may be misleading.

Many of the trials that showed a clinically significant effect on complete fracture healing in humans were retrospective with potential flaws in their methodology. Overall the evidence in humans is inconclusive, and, as there are many studies on fracture healing that would have been expected to show an effect of NSAIDs but did not, it is possible that the
What is already known on this topic

There is evidence from animal studies that NSAIDs can adversely affect fracture healing.

\section{What this study adds}

There is no conclusive evidence to document any effect of NSAIDs on stress fracture healing in humans. Until such evidence is produced, it is prudent to limit their use in patients with proven stress fracture.

available evidence showing a link may represent publication bias.

In view of the easy availability and common use of NSAIDs to treat a variety of soft tissue and bony injuries, and the failure to answer the original question, formal studies investigating the possible impairment of stress fracture healing with the use of NSAIDs are required. Further studies are also required to assess whether COX-2 inhibitors affect bone healing differently from non-specific NSAIDs in a clinical setting. Until the results of this research are available, the option of least risk is to avoid the use of NSAIDs in the treatment of stress fractures wherever possible.

\section{Authors' affiliations \\ P Wheeler, Leicester General Hospital, Leicester, UK \\ M E Batt, Queens Medical Centre, Nottingham, UK \\ Competing interests: none declared}

\section{REFERENCES}

1 Fredericson $M$, Bergman AG, Hoffman $K L$, et al. Tibial stress reaction in runners. Correlation of clinical symptoms and scintigraphy with a new magnetic resonance imaging grading system. Am J Sports Med 1995;23:472-81.

2 Giannoudis PV, MacDonald DA, Matthews SJ, et al. Nonunion of the femoral diaphysis. The influence of reaming and non-steroidal anti-inflammatory drugs. J Bone Joint Surg [Br] 2000;82:655-8.

3 Clough TM. Femoral neck stress fracture: the importance of clinical suspicion and early review. Br J Sports Med 2002;36:308-9

4 Bennell K, Brukner P. How should you treat a stress fracture? In: MacAuley D, Best T, eds. Evidence based sports medicine. London: BMJ Books, 2002;26:491-517.

5 Rang HP, Dale MM. In: Pharmacology, 2nd ed. Edinburgh: Churchill Livingstone Books, 1991

6 British National Formulary 46th ed (September 2003). London: British Medical Association/Royal Pharmaceutical Society of Great Britain.

6a Burrows $\mathrm{H}$. Fatigue infraction of the middle of the tibia in ballet dancers. J Bone Joint Surg [Br] 1956;38:83-94.

$7 \mathrm{Ha} \mathrm{KI}, \mathrm{Hahn} \mathrm{SH}$, Chung MY, et al. A clinical study of stress fractures in sports activities. Orthopedics 1991;14:1089-95.

8 Batt ME, Kemp S, Kerslake R. Delayed union stress fractures of the anterior tibia: conservative management. Br J Sports Med 2001;35:74-7.

9 van Staa T, Leufkens H, Cooper C. Use of nonsteroidal anti-inflammatory drugs and risk of fractures. Bone 2000;27:563-8.

10 Zhang $X$, Zhang Y, Schwartz E, et al. Cyclooxygenases and bone repair. Current Opinion in Orthopaedics 2001;12:397-402.

11 Zhang X, Schwartz EM, Young DA, et al. Cyclooxygenase-2 regulates mesenchymal cell differentiation into the osteoblast lineage and is critically involved in bone repair. J Clin Invest 2002;109:1405-15.

12 Penman D. No pain, no gain? New Scientist 2002;174(2346):6.

13 Siwek J, Gourlay ML, Slawson DC, et al. How to write an evidence-based clinical review article. Am Fam Physician 2002;65:251-8.

14 Reuben SS, Connelly NR, Lurie S, et al. Dose-response of ketorolac as an adjunct to patient-controlled analgesia morphine in patients after spinal fusion surgery. Anesth Analg 1998:87:98-102.

15 Matsumura J, Reuben SS. Considerations in the use of COX-2 inhibitors in spinal fusion surgery response. Anesth Analg 2001;93:803-4.

16 Allen H, Wase A, Bear W. Indomethacin and aspirin: effect of nonsteroidal anti-inflammatory agents on the rate of fracture repair in the rat. Acta Orthop Scand 1980:51:595-600.

17 Altman RD, Latta LL, Keer R, et al. Effect of nonsteroidal antiinflammatory drugs on fracture healing: a laboratory study in rats. J Orthop Trauma 1995;9:392-400. 
18 Elves M, Bayley I, Roylance P. The effect of indomethacin upon experimental fractures in the rat. Acta Orthop Scand 1982;53:35-41.

19 Hogevold H, Grogaard B, Reikeras O. Effects of short-term treatment with corticosteroids and indomethacin on bone healing. A mechanical study of osteotomies in rats. Acta Orthop Scand 1992:63:607-11.

20 Sudmann E, Hagen T. Indomethacin-induced delayed fracture healing. Arch Orthop Unfallchir 1976;85:151-4.

21 Bo J, Sudmann E, Marton P. Effect of indomethacin on fracture healing in rats. Acta Orthop Scand 1976:47:588-99.

22 Sudmann E, Tveita T, Hald J. Lack of effect of indomethacin on ordered growth of the femur in rats. Acta Orthop Scand 1982;53:43-9.

23 Adolphson $P$, Abbaszadegan $H$, Jonsson $U$, et al. No effects of piroxicam on osteopenia and recovery after Colles' fracture. A randomized, double-blind, placebo-controlled, prospective trial. Arch Orthop Trauma Surg 1993:112:127-30.

24 Burd T, Hughes M, Anglen J. Heterotopic ossification prophylaxis with indomethacin increases the risk of long-bone nonunion. J Bone Joint Surg $[\mathrm{Br}]$ 2003;85:700-5.
25 Butcher CK, Marsh DR. Nonsteroidal anti-inflammatory drugs delay tibial fracture union. Injury 1996;27:375

26 Khan M. Fracture healing: role of NSAIDs. Am J Orthop 1997;26:413.

27 Alho A, Benterud J, Solovieva S. Internally fixed femoral neck fractures. Early prediction of failure in 203 elderly patients with displaced fractures. Acta Orthop Scand 1999;70:141-4.

28 Karladani AH, Granhed H, Karrholm J, et al. The influence of fracture etiology and type on fracture healing: a review of 104 consecutive tibial shaft fractures. Arch Orthop Trauma Surg 2001;121:325-8.

29 Perlman M, Thordarson D. Ankle fusion in a high risk population: an assessment of nonunion risk factors. Foot Ankle Int 1999;20:491-6.

30 Glassman SD, Rose SM, Dimar JR, et al. The effect of postoperative nonsteroidal anti-inflammatory drug administration on spinal fusion. Spine 1998;23:834-8.

31 Anon. NSAIDs and bone. Bandolier Extra 2001

32 Anon. NSAIDs and fracture risk. Bandolier 2001:94.

\section{ELECTRONIC PAGES}

\section{Online case and short reports}

$\mathrm{T}$

he following electronic only articles are published in conjunction with this issue of BJSM (see also pages 101 and 110$)$

\section{Quadrilateral space syndrome: a case study and review of the literature \\ W T Hoskins, H P Pollard, A J McDonald}

Quadrilateral space syndrome is an uncommon injury. The true prevalence is unknown because of a lack of literature and possible misdiagnosis. Prevalence may increase as knowledge of the syndrome increases. The case is presented of a recreational triathlete who had a spontaneous onset of quadrilateral space syndrome. The diagnosis was made by physical examination and confirmed with magnetic resonance imaging. A conservative, yet aggressive rehabilitation programme resulted in functional improvement within six weeks. Results have been maintained for eight weeks.

(Br J Sports Med 2005;39:e9) http://bjsm.bmjjournals.com/ cgi/content/full/39/1/e9

\section{Prevalence of headache in Australian footballers P McCrory, J Heywood, C Coffey}

Objective: To survey the prevalence and risk factors for headache in a population of elite professional Australian footballers.

Methods: A prospective questionnaire based survey was performed on elite Australian footballers participating in a national competition. The survey was designed to assess the prevalence and risk factors for headache using standardised International Headache Society (HIS) criteria. Headache prevalence was compared with that of an age and sex matched community control population.

Results: A total of 160 questionnaires were analysed. Headaches were reported by $80 \%$ of subjects, with $49 \%$ of respondents reporting headaches during competitive match play and $60 \%$ during training. There was no significant difference between the footballers and the community sample in the number of headaches ever; however, they did report more headaches in the three months before the survey-that is, during the competitive playing season. In the footballers, $22 \%$ of headaches conformed to the strict IHS definition of migraine headaches. When the relaxed definition of "footballers migraine" was used, 34\% of headaches met these criteria. Footballers were at significantly increased risk of footballer's migraine than community controls.

Conclusions: Headaches are common in Australian footballers, and the prevalence of migraine is increased in relation to community prevalence studies. Furthermore, the strict HIS criteria may not adequately identify the specific subtype of football related headache. This finding has important implications in the management of headache in this setting.

(Br J Sports Med 2005;39:el0) http://bjsm.bmjjournals.com/ cgi/content/full/39/1/el0 